\title{
EDITORIAL
}

\section{FORTALECENDO A PROFISSÃO}

Ganhar. Perder. Viver: é um lema de vida. Nos últimos sete anos, quais as vitórias que podem ser contadas no evoluir da assistência de enfermagem e dos que a produzem? Convidamos nossos leitores a fazer uma ligeira avaliação.

1. Há sete ancs, depois de um período longo de tentativa infrutífera para convencer alguns tecnocratas sobre a necessidade de o País formar recursos humanas de enfermagem, houve a magnífica providência de traçarem-se metas e de se abrirem cursos de graduação em enfermagem, - a princípio naquelas universidades federais em que inexistiam tais cursos. Trata-se de um importante projeto levado à ação pela Secretaria de Ensino Superior do Ministério da Educação e Cultura; foram, desse modo, aumentados em $70 \%$ tais cursos de graduação. Também nessa linha de educação, o ano de 1975 viu aumentar, em porcentagem maior, os cursos de pós-graduação - de mestrado e doutorado em enfermagem. $O$ interesse dos jovens pela carreira de enfermagem mantém-se em bom nível nos exames vestibulares.

2. Mas, ainda assim, são insuficientes os enfermeiros nas instituições de saúde. A procura dos serviços de saúde se expande, e não aumenta, na mesma proporção, o número de enfermeiros contratados nesses serviços. Há uma carência daquele pessoal de enfermagem de $2 .^{\circ}$ grau de ensino; essa carência agrava a situação. No final da década de 1950, o Levantamento dos Recursos e Necessidades de Enfermagem, pesquisa realizada pela $A B E n$, encontrara $70 \%$ de atendentes no conjunto do pessoal de enfermagem, inclusive enfermeiros e auxiliares de enfermagem, nos serviços de saúde do país.

Felizmente, de 1975 em diante, há um aumento de habilitação de técnicos de enfermagem e auxiliares de enfermagem (Resolução do Conse. tho Federal de Educação n. ${ }^{.8} 7$ e 8 de 1977) no ensino singular e nas suplências profissionalizantes. Estas últimas substituiram com vantagem as habilitações precaríssimas segundo o antigo Decreto-lei $n .^{\circ} 8.778 \mathrm{de}$ 1946. Quanto às suplências profissionalizantes, elas vão ajudar aqueles 
que não puderam fazer curso regular, mas precisam melhorar suas condiçōes de emprego e sua promoção social. Se trazem para as estabelecimentos de saúde pessoal pouco capacitado tecnicamente, competirá a essas instituiçōes organizar treinamentos de orientação inicial e de educação continuada para os melhorar. Estamos num País de grandes necessidades quanto a estes aspectos do trabalho e temos de contribuir para o progresso de todos. Justamente, este aspecto de educação continuada tem de ser encarado pelos enfermeiros dirigentes de enfermagem dos setores de internação e demais da assistência à saúde. A própria Lei n. ${ }^{\circ} 5.905$, de 1973, que criou os Conselhos de Enfermagem, determina que haja aperfeicoamento no trabalho.

3. Finalmente, a grande modificação para melhor, que os serviços de enfermagem deverão ter nos anos próximos, deve advir da existência dos Conselthos Federal (COFEN) e Regionais (CORENs) de Enfermagem. Eles foram instalados em 1975. Um dos maiores trabalhos realizados pelo Conselho Federal de Enfermagem tem sido aquele em que, mobilizando o ponto de vista de todas as entidades sindicais e culturais em que se agremiava, naquela época, pessoal de enfermagem, conseguiu elaborar o anteprojeto de uma futura lei do exercício profissional (que deverá substituir a defasada Lei n.o 2.604 de 1955). Temos o dever de, em união de esforços, tudo fazer para ajudar o Conselho Federal de Enfermagem a ver sancionada essa nova lei. "Ganhar, perder, viver!" Está na hora de termos bom senso e de cerrarmos fileira, unidos, para que os serviços de enfermagem deste país se organizem e tenham um desempenho à altura do que já sabemos ser exequivel. Estamos recusando continuar com um nivel indesejável de serviços de enfermagem. Unidos, sabendo o que queremos, podemos ganhar essa batalha de vida.

(HGD) 